\title{
SISTEM UPAH MINIMUM KABUPATEN DALAM PERSPEKTI ISLAM (Studi Kasus Pada Upah Minimum Kabupaten Sidoarjo) 1)
}

\author{
Rachmad Firmansyah \\ Mahasiswa Program Studi S1 Ekonomi Islam-Fakultas Ekonomi dan Bisnis-Universitas Airlangga \\ Email : rachmad.firmansyah-11@feb.unair.ac.id \\ Moh. Qudsi Fauzy \\ Departemen Ekonomi Syariah-Fakultas Ekonomi dan Bisnis-Unversitas Airlangga \\ Email : qudsi.fauzy@feb.unair.ac.id
}

\begin{abstract}
:
Islam does not allow wages under the minimum level based on the basic needs of groups of workers; nor let their wage increases that exceed a certain level determined based on his contribution to production. Employers need workers to run its business to remain in existence, while workers need the work to make ends meet. Islam tries to create a fair balance between the two, both in terms of remuneration and protection of the interests of workers and employers. There are three parameters in Islam as basis in determining the appropriate wage system of sharia, namely Justice, Feasibility and Virtue. The state has important roles in giving attention to the workers in earning sufficient wages to sustain a level of decent living and not allow wages under the minimum levels.
\end{abstract}

\section{Keywords: Policy, Welfare, Minimum Wage, Wage in the perspective of Islam}

\section{PENDAHULUAN}

\section{Latar Belakang}

Ketenagakerjaan merupakan

masalah mendasar yang dihadapi oleh hampir seluruh negara di dunia tak terkecuali di Indonesia sekalipun. Permasalah ketenagakerjaan ini bersifat multidimensi, mempengaruhi dan dipengaruhi oleh berbagai faktor dengan pola hubungan yang kompleks, sehingga penyelesaiannya menuntut arah kebijakan yang multidimensi pula.

Undang-undang pasal 88 Nomor 13 Tahun 2003 tentang ketenagakerjaan menyebutkan bahwa pemerintah menetapkan kebijakan pengupahan yang melindungi pekerja. Kebijakan pengupahan tersebut salah satunya dengan penetapan upah minimum yang ditetapkan secara sektoral maupun regional. Pemerintah dalam menetapkan upah minimum tersebut dengan memperhatikan produktifitas, pertumbuhan ekonomi serta memperhatikan usaha-usaha yang paling tidak mampu (marginal).

Manfaat yang didapat dengan ditetapkan upah minimum menurut Sumarsono (2003:147) adalah untuk (a) menjamin penghasilan pekerja sehingga tidak lebih rendah dari suatu tingkat tertentu, (b) meningkatkan produktivitas pekerja, (c) mengembangkan dan meningkatkan perusahaan dengan caracara yang lebih efisien.

Konteks pengupahan apabila ditinjau dari sudut pandang ekonomi Islam, menjelaskan bahwa besaran upah ditetapkan oleh kesepakatan antara pengusaha dan pekerja. Kedua belah

1) Jurnal ini merupakan bagian dari skripsi dari Rachmad FirmanSyah, NIM: 041114003 , yang diuji pada tanggal 11 Agustus 2016 
FirmanSyah, et al/Jurnal Ekonomi Syariah Teori dan Terapan Vol. 4 No. 6 Juni 2017: 434-448; SISTEM UPAH MINIMUM KABUPATEN DALAM PERSPEKTI ISLAM (Studi Kasus Pada Upah Minimum Kabupaten Sidoarjo)

pihak memiliki kebebasan untuk menetapkan jumlah upah, serta bebas menetapkan syarat dan cara pembayaran upah tersebut. Asalkan saling rela dan tidak merugikan salah satu pihak.

Dalam Islam tidak ada pedoman penentuan penetapan besaran upah yang pantas dan layak diberikan kepada pekerja, Islam hanya mengajarkan bagaimana orang yang bekerja hendaknya mendapatkan upah atas jasa yang diberikan pengusaha kepadanya selain itu Islam mengajarkan kita untuk selalu berlaku adil.

Sistem pengupahan yang baik akan menentukan kesejahteraan bagi pekerja. Hal ini akan berdampak bagi masa depan perusahaan. Dengan upah yang layak diharapkan pekerja dapat lebih termotivasi meningkatkan kinerjanya dalam berproduksi, sehingga dapat memajukan perusahaan itu sendiri.

\section{LANDASAN TEORI}

Definisi upah menurut Sumarsono (2009:181) merupakan suatu penerimaan sebagai imbalan dari pengusaha kepada karyawan untuk suatu pekerjaan atau jasa yang telah atau akan dilakukan dan dinilai dalam bentuk vang yang diterapkan atas dasa suatu persetujuan atau perundang-undangan. Upah yang dibayarkan juga termasuk tunjangan, baik untuk dirinya sendiri maupun untuk keluarganya.

Berbagai pandangan pengertian mengenai upah baik dari sisi pekerja maupun pengusaha sumarsono (2003:157) menguraikannya sebagai berikut :

1. Upah bagi pengusaha adalah biaya yang harus dibayarkan kepada buruh dan diperhitungkan dalam penentuan biaya total.

2. Upah bagi buruh adalah pendapatan yang diperoleh dari penghasilan menggunakan tenaganya kepada produsen.

Perbedaan pengertian mengenai upah tersebut menurut Simanjuntak (1998:131) dapat menimbulkan permasalahan tersendiri mengenai upah. Bagi pengusaha, upah dapat dipandang beban produksi, karena semakin besar upah yang dibayarkan kepada pekerja semakin kecil proporsi keuntungan bagi pengusaha. Sehingga beban produksi tersebut harus ditekan serendahrendahnya Di pihak lain, pekerja menganggap upah hanya sebagai apa yang diterimanya dalam bentuk uang (take-homepay).

Sistem pengupahan di Indonesia pada umumnya berdasarkan pada tiga fungsi upah, yaitu :

1. Menjamin kehidupan yang layak bagi pekerja dan keluarganya (fungsi sosial).

2. Mencerminkan imbalan atas hasil kerja seseorang.

3. Menyediakan insentif untuk mendorong meningkatkan produktivitas kerja dan pendapatan nasional (Simanjuntak, 1998:125).

Ketentuan Peraturan Menteri Tenaga Kerja No. Per-01/Men/1999 pasal 1 mengenai Upah Minimum yang 
FirmanSyah, et al/Jurnal Ekonomi Syariah Teori dan Terapan Vol. 4 No. 6 Juni 2017: 434-448; SISTEM UPAH MINIMUM KABUPATEN DALAM PERSPEKTI ISLAM (Studi Kasus Pada Upah Minimum Kabupaten Sidoarjo)

mendefiniskan bahwa Upah Minimum adalah upah bulanan terendah yang terdiri dari upah pokok termasuk tunjangan. (Tjandra dkk, 2007:101)

Kemudian dipertegas dalam Undang-undang Nomor 13 tahun 2003 yang menyatakan bahwa upah minimum hanya ditujukan bagi pekerja dengan masa kerja 0 (nol) sampai dengan 1 (satu) tahun, dijelaskan pula bahwa upah minimum harus berdasarkan kebutuhan hidup layak (KHL) dan dengan memperhatikan produktivitas dan pertumbuhan ekonomi, di mana Upah Minimum bertujuan untuk memenuhi $\mathrm{KHL}$ (Tjandra dkk, 2007:15).

Peraturan mengenai Kebutuhan hidup layak (KHL) diatur dalam Peraturan Menteri Tenaga Kerja dan Transmigrasi No17 Tahun 2005 tentang komponen dan pelaksanaan tahapan pencapaian kebutuhan hidup layak (KHL), yang yang menyatakan bahwa KHL adalah standar kebutuhan yang harus dipenuhi oleh seorang buruh lajang untuk dapat hidup layak baik secara fisik, non-fisik dan sosial, untuk kebutuhan satu bulan, dan berlaku bagi buruh dengan masa kerja kurang dari satu tahun (Tjandra dkk, 2007:15).

Menurut Peraturan Menteri Tenaga Kerja Nomor 01/Men/1999 pasal 3 jenis upah minimum yang ditetapkan adalah sebagai berikut ; (Tjandra dkk, 2007:1 15)

1. Upah Minimum Sektoral Provinsi (UMS Provinsi) yaitu upah minimum yang berlaku secara sektoral di seluruh Kabupaten/Kota di satu Provinsi.
2. Upah Minimum Sektoral Kabupaten/Kota (UMS Kabupaten/Kota), yaitu upah minimum yang berlaku secara sektoral di daerah Kabupaten/kota.

3. Upah Minimum Kabupaten/Kota (UMK), yaitu upah minimum yang berlaku di Daerah Kabupaten/Kota.

4. Upah Minimum Regional atau Upah Minimum Provinsi, yaitu upah minimum yang berlaku untuk semua seluruh Kabupaten/Kota di satu Provinsi.

Sebagaimana diatur dalam pasal 4 Peraturan Menteri Tenaga Kerja Bo. 17/2005, upah minimum ditetapkan dengan mempertimbangkan hal-hal berikut :

1. Kebutuhan Hidup Layak (KHL).

2. Produktivitas (jumlah Produk Domestik Regional Bruto/PDRB: jumlah tenaga kerja pada periode yang sama)

3. Pertumbuhan ekonomi (pertumbuhan nilai PDRB).

4. Usaha yang paling tidak mampu (marginal). (Tjandra, 2007:15)

Selanjutnya untuk Untuk UMP dan UMK, seta UMSProp dan UMSKab, dutetapkan dengan mempertimbangkan hal-hal sebagai berikut:

1. Kebutuhan

2. Indeks harga konsumen (IHK)

3. Kemampuan, perkembangan dan kelangsungan perusahaan

4. Upah pada umumnya yang berlaku di daerah tertentu dan antar daerah

5. Kondisi pasar kerja

6. Tingkat perkembangan perekonomian dan pendapatan per kapita. 
7. Khusus untuk UMSProp dan UMSKab juga mempertimbangkan kemampuan perusahaan secara sektoral (Tjandra, 2007:16)

Kemudian pada Peraturan Menteri Tenaga Kerja Nomor 7 Tahun 2013 pasal 12 UMP dan UMK ditetapkan oleh Gubernur dengan memperhatikan rekomendasi Dewan Pengupahan Provinsi dan rekomendasi bupati/walikota. Rekomendasi yang dimaksud melalui Satuan Kerja Perangkat Daerah Provinsi yang bertanggung jawab di bidang ketenagakerjaan.

Penentuan upah minimum disahkan setelah diadakan petemuan oleh 3 pihak yang terkait atau yang sering dikenal dengan sebutan Tripartit yakni :

1. Pihak tenaga kerja selaku pihak yang menerima upah, disini pihak tenaga diwakilkan oleh perwakilan dari serikat buruh yang telah dibentuk oleh para pekerja itu sendiri.

2. Pihak pengusaha selaku pihak yang membayar upah kepada paa pekerja atas kinerja dan output yang dihasilkan oleh pekerja, biasanya pihak pengusaha diwakilkan oleh ikatan pengusaha.

3. Pihak pemerintah selaku pihak ketiga yang menjadi penengah antara pihak tenaga kerja dengan pihak pengusaha.

Setelah semua pihak menyetujui penetapan upah tersebut maka pemerintah mengesahkan upah minimum yang telah disepakati (Muliawan, 2011).
Dalam Islam upah merupakan hak dan bukan pemberian sebagai hadiah.Menurut Afzalurrahman (1995:361) memberikan pengertian bahwa upah merupakan sebagian harga dari tenaga (pekerjaan) yang dibayarkan atas jasanya dalam produksi.

Beberapa hal yang membedakan konsep pengupahan dalam islam dengan konsep pengupahan konvesional. Hal ini dapat dilihat dalam tabel 1 dibawah ini

Tabel 1.

Teori Konsep Upah dalam Islam

\begin{tabular}{|c|c|c|c|}
\hline No & Aspek & $\begin{array}{c}\text { Ekonomi } \\
\text { Konvensional }\end{array}$ & Ekonomi Islam \\
\hline 1 & $\begin{array}{l}\text { Adanya ketetkatan yang erat antara upah } \\
\text { dengan moval }\end{array}$ & Tiddk & $\mathrm{Ya}_{\mathrm{a}}$ \\
\hline 2 & $\begin{array}{l}\text { Upads memiliki dua dimensi, yatu Dumia } \\
\text { dan Akhirirat }\end{array}$ & Tidak & $\mathrm{Ya}$ \\
\hline 3 & Upath dibentkan dengan prinsip keadillan & $\mathrm{Ya}_{\mathrm{a}}$ & $Y_{a}$ \\
\hline 4 & $\begin{array}{l}\text { Upah dibenklkan berdasarkan prinsip } \\
\text { kelayakan }\end{array}$ & $\mathrm{Ya}_{2}$ & $\mathrm{Ya}_{\mathrm{a}}$ \\
\hline
\end{tabular}

Upah dalam konsep Islam menekankan pada dua aspek, yaitu aspek dunia secara langsung dan aspek akhirat. Akan tetapi hal yang paling penting adalah bahwa penekanan pada akhirat lebih diutamakan.

Dalam Islam Upah dimasukkan ke dalam wilayah fiqih muamalah, yakni dalam pembahasan tentang ujarah atau ijarah. ljarah berasal dari kata al-Ajru yang 
arti menurut bahasanya ialah al-'-'Iwadh.

Dalam bentuk lain, kata ijarah juga biasa dikatakan sebagai nama bagi al-ujrah yang artinya ialah ganti dan upah.

Dalam prespektif Islam menurut para ulama upah dapat digolongkan menjadi 2 (dua), yaitu :

1. Upah yang telah disebutkan (ajr almusamma), yaitu upah yang telah disebutkan pada awal transaksi, syaratnya adalah ketika disebutkan harus disertai adanya kerelaan (diterima oleh kedua belah pihak).

2. Upah yang sepadan (ajr al-mitli) adalah upah yang sepadan dengan kerjanya serta sepadan dengan kondisi pekerjaannya. Maksudnya adalah harta yang dituntut sebagai kompensasi dalam suatu transaksi yang sejenis pada umumnya. (Huda, 2008:230).

Dalam menetapkan upah, menurut Afzalurrahman (1995:297) mengatakan bahwa upah akan ditentukan melalui negoisasi di antara pekerja (buruh), majikan (pengusaha) dan negara. Kepentingan pengusaha dan pekerja akan diperhitungkan dengan adil sampai pada keputusan tentang upah. Tugas negara adalah memastikan bahwa upah ditetapkan dengan tidak terlalu rendah sehingga menafikan kebutuhan hidup para pekerja atau buruh, tetapi tidak juga terlalu tinggi sehingga menafikan bagian si pengusaha dari hasil produk bersamanya.
Sedangkan Yusuf al-Qaradawi (1997:233) ada dua hal yang perlu diperhatikan yaitu nilai kerja dan kebutuhan hidup. Nilai kerja menjadi pijakan penetapan upah, karena tidak mungkin menyamaratakan upah bagi buruh terdidik atau buruh yang tidak mempunyai keahlian, sedangkan kebutuhan pokok harus diperhatikan karena berkaitan dengan kelangsungan hidup buruh.

Sumber dasar hukum upah yang dipakai dalam Islam adalah dengan menggunakan Al-Qur'an dan Sunnah Nabi, yang salah satunya pada Al-Qur'an surat Al-Ahqaf ayat 19 :
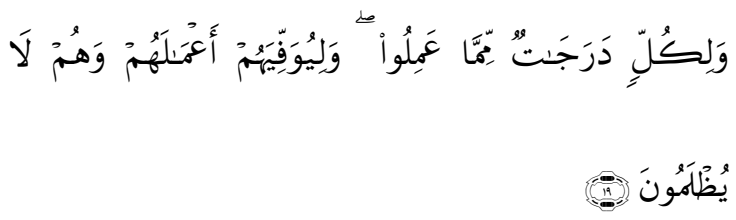

Wa likullin darajātum mimmā'amilū, wa liyuwaffiyahum a'mālahum wa hum $l \bar{a}$ yuzlamūn.

Artinya : "dan bagi masing-masing mereka derajat menurut apa yang telah mereka kerjakan dan agar Allah mencukupkan bagi mereka (balasan) pekerjaan-pekerjaan mereka sedang mereka tiada dirugikan." (Departemen Agama Republik Indonesia, 2007:1065)

Berdasarkan pada ayat di atas, menunjukkan bahwa risalah upah telah disyari'atkan oleh Allah dan wajib dibayarkan sebagai kompensasi atau balasan dan sekaligus merupakan hak bagi pekerja atau buruh dengan cara menjunjung tinggi nilai-nilai keadilan dan kelayakan sesuatu dengan bantuan atau 
tenaga yang telah diberikan oleh pekerja atau buruh (Mustofa, 2009). Untuk itu, upah yang dibayarkan pada masingmasing pegawai bisa berbeda berdasarkan jenis pekerjaan dan tanggung jawab yang dipikulnya.

Prinsip-prinsip yang menjadi dasar sebagai penetapan upah dan besaran upah menurut syari'ah adalah kesepakatan antara kedua belah pihak dengan pertimbangan prinsip keadilan, prinsip kelayakan, dan prinsip kebajikan menurut Azhar Basyir dalam Mustofa (2009) :

1. Prinsip keadilan

Dalam hal keadilan, Azhar Basyir mengatakan terpenuhinya dua model keadilan dalam pemberian upah pada buruh, yaitu: 1) keadilan distributif, menuntut agar para buruh yang mengerjakan pekerjaan yang sama dengan kemampuan kadar kerja yang berdekatan memperoleh imbalan atau upah yang sama tanpa memperhatikan kebutuhan perorangan dan keluarganya. 2) keadilan harga kerja, menuntut pada buruh untuk memberikan upah yang seimbang dengan tenaga yang diberikan tanpa dipengaruhi oleh hukum penawaran dan permintaan yang menguntungkan pemilik perusahaan. Adil mempunyai bermacam-macam makna, yang diantaranya :
a. Adil bermakna jelas
b. Adil bermakna proposional.

2. Prinsip Kelayakan

Pengertian layak diartikan sebagai cukup pangan, sandang, papan dan sesuai pasaran. Hal ini di dasarkan pada Al-Qur'an surat Thaaha ayat 118119 :

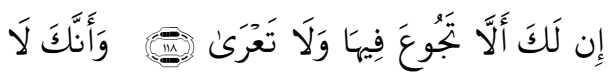

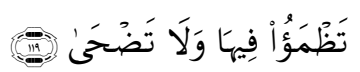

Inna laka allā tajū 'a fihā wa lā ta 'rā. Wa annaka lā tazma'u fihā wa lā tadhā

Artinya : "Sesungguhnya kamu tidak akan kelaparan di dalamnya dan tidak akan telanjang, dan Sesungguhnya kamu tidak akan merasa dahaga dan tidak (pula) akan ditimpa panas matahari di dalamnya." (Departemen Agama Republik Indonesia, 2007:644)

Menurut Shihab (2002:384) dalam tafsirnya mengatakan Sesungguhnya engkau tidak lapar sesaatpun di dalam surga karena pangan yang melimpah dan tidak akan telanjang karena pakaian tersedia beraneka ragam dan tidak akan merasa dahaga, dan kata "Tadha" dipahami dalam arti tidak disengat matahari, banyak ulama' yang memahaminya dalam arti naungan yakni rumah. Ayat diatas menyebut dengan teliti kebutuhan pokok manusia kapan di manapun mereka berada yaitu pangan, sandang dan papan. Hal itulah yang akan bersifat material minimal yang harus dipenuhi manusia.

3. Prinsip Kebajikan 
Prinsip kebajikan yang dalam hubungan kerja dapat diterjemahkan sebagai asas kerohanian dan diharapkan mampu menggugah hati nurani para pemilik pekerja untuk dapat menghargai jasa para buruh atau pekerja yang telah memberikan sumbangan untuk mendapatkan kekayaan yang lebih.

Masruri (2011) menjelaskan Islam memberikan acuan pedoman dalam penentuan upah secara islami adalah sebagai berikut :

1. Islam memberikan pengupahan berdasarkan hasil.

2. Islam dalam memberikan upah tidak melihat sisi gender, tetapi berdasarkan apa yang dikerjakannya.

3. Dari sisi waktu, semakin cepat semakin baik.

4. Dari sisi keadilan, pekerjaan yang sama dengan hasil yang sama, seharusnya dibayar dengan bayaran yang sama pula (proporsional).

5. Dalam memberikan upah, besaran minimal pekerjaan tersebut dapat memenuhi kebutuhan dasarnya berdasarkan ukuran umum masyarakat.

Berdasarkan landasan teori yang telah dijelaskan, maka dapat dirancang kerangka berpikir sbagai berikut:

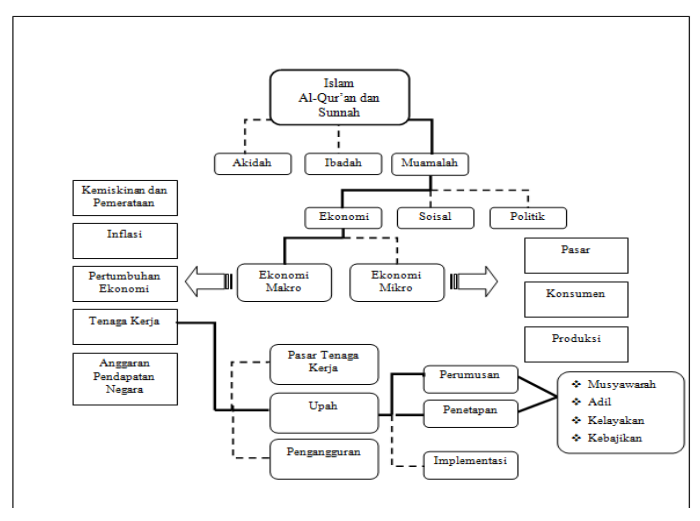

Sumber : Peneliti

Gambar 1. Kerangka Berpikir

\section{METODE PENELITIAN}

\section{Pendekatan Penelitian}

Penelitian ini menggunakan pendekatan penelitian kualitatif. Dimana data yang terkumpul akan diolah dan dianalisis secara deskriptif. Penelitian kualitatif merupakan penelitian yang menekankan pada proses yaitu tidak menjadikan hasil penelitian sebagai orientasi keberhasilan suatu data melainkan kebenaran dari hipotesis yang disajikan melalui hasil penelitian gejala sosial yang ada. Menurut Yin (2009; 2) pendekatan kualitatif adalah pendekatan dengan menggunakan data yang berupa kalimat tertulis atau lisan, peristiwaperistiwa, pengetahuan yang bersifat deskriptif.

\section{Ruang Lingkup Penelitian}

Penelitian yang dimaksud adalah untuk menjawab rumusan masalah "Bagaimanakah proses perumusan dan penetapan kebijakan pengupahan yang dijalankan di Kabupaten Sidoarjo. Rumusan masalah tersebut menjadi acuan oleh peneliti dalam dalam melakukan penentuan ruang lingkup penelitian ini". Rumusan masalah tersebut yang akan menjadi acuan bagi peneliti untuk menentukan ruang lingkup penelitian. Batasan/ruang lingkup dalam penelitian ini adalah: 
A. Penelitian ini difokuskan pada proses pembuatan dan perumusan kebijakan Upah Minimum yang ditetapkan di Sidoarjo.

B. Membatasi penelitian ini hanya bagaimana proses terbentuknya Upah Minimum Kabupaten (UMK) Sidoarjo sampai pada akhirnya ditetapkan

\section{Jenis dan Sumber Data}

Menurut Lofland sumber data utama dalam penelitian kualitatif adalah katakata dan tindakan, selebihnya adalah data tambahan seperti dokumen dan lain-lain (Moelong 2011:157). Berkaitan dengan itu, jenis data dibagi kedalam kata-kata dan tindakan, sumber data tertulis, foto dan statistik (Moelong, 2011:157).

1. Kata-kata dan tindakan

Kata-kata dan tindakan orang-orang yang diamati atau diwawancarai merupakan sumber data utama (Moelong, 2011:157). Pencatatan sumber data utama melalui wawancara atau pengamatan yang merupakan hasil dari melihat, mendengar dan bertanya (Moelong, 2011:157). Catatan tertulis diperoleh dengan cara mencatat setiap peristiwa berupa perilaku subjek penelitian dan berdasarkan rekaman audio ketika wawancara dengan beberapa pihak terkait dengan yang terlibat dalam perumusan dan penetapan upah minimum di Kabupaten Sidoarjo. Informan yang menjadi sumber data ini adalah perwakilan dari organisasi buruh, perwakilan dari organisasi pengusaha (APINDO), perwakilan dari akademisi dari pergurvan tinggi Universitas Airlangga, dan Kepala bagian di DISNAKER Sidoarjo.

2. Sumber tertulis

Sumber tertulis berasal dari buku, majalah ilmiah, sumber dari arsip, dokumen pribadi, dan dokumen resmi (Moleong, 2011:159). Sumber tertulis penelitian ini berasal dari buku, jurnal, surat kabar online, dokumen pribadi, dan dokumen resmi yang berkenaan dengan judul penelitian.

3. Foto

Foto menghasilkan data deskriptif yang cukup berharga dan sering digunakan untuk menelaah segi-segi subjektif dan hasilnya sering dianalisa secara induktif (Moleong, 2011:160). Foto yang ada dipenelitian ini berkaitan dengan judul pada penelitian ini. Foto yang ada menjadi sumber bukti pelengkap dalam proses penelitian.

\section{Teknik Pengambilan Informan}

Penelitian ini menggunakan teknik purposive. Menurut Sugiyono (2013:218) purposive sampling adalah teknik pengambilan sampel sumber data dengan pertimbangan tertentu. Pertimbangan tertentu ini, misalnya informan tersebut dianggap memahami informasi sehingga akan memudahkan peneliti menjelajahi obyek atau situasi sosial yang diteliti.

Dalam penelitian ini diambil informan utama diantaranya asosiasi pengusaha 
FirmanSyah, et al/Jurnal Ekonomi Syariah Teori dan Terapan Vol. 4 No. 6 Juni 2017: 434-448; SISTEM UPAH MINIMUM KABUPATEN DALAM PERSPEKTI ISLAM (Studi Kasus Pada Upah Minimum Kabupaten Sidoarjo)

dan serikat buruh yang ada di daerah Kabupaten Sidoarjo. Untuk memeperoleh informan ditetapkan beberapa kriteria yang penerapannya bersifat purposive sampling dan dalam penelitian ini informan yang akan diteliti adalah diantaranya sebagai berikut :

1. Asosiasi pengusaha yang memiliki wakilnya sebagai anggota di Dewan Pengupahan Kabupaten Sidoarjo.

2. Asosiasi buruh yang memiliki wakilnya sebagai anggota di Dewan Pengupahan di Kabupaten Sidoarjo.

\section{Prosedur dan Teknik Pengumpulan Data}

Teknik pengumpulan data yang dilakukan di dalam penelitian ini adalah wawancara mendalam (in-depth interview), observasi partisipan, dan studi dokumentasi.

Pengumpulan data adalah prosedur yang sistematis dan standar untuk memperoleh data yang diperlukan (Nazir, 2003:174). Data primer dikumpulkan dengan tahap sebagai berikut :

1. Persiapan awal

Pada tahap ini, penulis mengurus surat ijin penelitian skripsi kepada Fakultas Ekonomi dan Bisnis Universitas Airlangga sebagai kelengkapan dalam rangka perijinan kepada pihak yang berwenang di wilayah yang ditempati oleh objek penelitian untuk melakukan pegumpulan data dari seluruh pihakpihak yang relevan dengan penelitian ini.

2. Proses memasuki lokasi dan wawancara objek penelitian
Pada tahap ini, awalnya peneliti menemui perwakilan dari Dinas Soisal dan tenaga kerja (DISNAKER) daerah Kabupaten Sidoarjo untuk mendapatkan informasi mengenai Perumusan dan Penetapan Upah Minimum yang terdapat di Kabupaten Sidoarjo serta menanyankan informasi kepada yang bersangkutan sebagai salah satu informan dalam penelitian ini berkaitan dengan upaya pengumpulan data untuk menjawab rumusan masalah dalam penelitian ini. Waktu pelaksanaan penggalian data tergantung pada kesepakatan yang telah dibuat.

Kemudian peneliti menemui Ketua atau salah satu perwakilan dari anggota Serikat buruh SPN untuk mendapatkan informasi mengenai keterlibatan buruh dalam Perumusan dan Penetapan Upah Minimum di Kabupaten Sidoarjo.

Setelah itu peneliti menemui Ketua atau salah satu perwakilan anggota Asosiasi Pengusaha Indonesia (APINDO) untuk mendapatkan informasi mengenai keterlibatan pengusaha dalam Perumusan dan Penetapan upah minimum di Kabupaten Sidoarjo.

Pada tahap akhir peneliti menemui para akademisi Universitas yang dianggap mengetahui secara pasti tentang kebijakan pengupahan dibuat.

3. Proses pengumpulan data

Pada tahap ini, peneliti mengumpulkan data dengan metode yang diperlukan. Peneliti menggunakan 
berbagai teknik kepada objek penelitian dalam menggali informasi yang diperlukan untuk menjawab rumusan masalah pada penelitian ini, antara lain peneliti akan mencatat dan merekam semua informasi yang diketahui dari objek penelitian tersebut yang kemudian hasil wawancara tersebut akan diinterpresikan sehingga dapat dijadikan hasil pembahasan dan simpulan dalam penelitian ini.

\section{Teknik Analisis Data}

Pada tahapan ini pembahasan dilakukan dengan cara membahas Apakah dalam proses-proses perumusan dan penetapan kebijakan Upah Minimum yang dijalankan di Kabupaten Sidoarjo telah memenuhi syarat-syarat adanya musyawarah, keadilan, kelayakan, dan kebajikan dalam prespektif Islam.

\section{HASIL DAN PEMBAHASAN}

\section{Mekanisme Perumusan dan Penetapan}

\section{Upah Minimum Kabupaten di Sidoarjo}

Kebijakan upah minimum ditujukan sebagai piranti perlindungan agar upah tidak berada pada level terendah akibat ketidak seimbangan antara permintaan dan penawaran tenaga kerja. Dalam Undang-undang pasal 88 Nomor 13 tahun 2003 tentang ketenagakerjaan menyebutkan bahwa setiap pekerja/buruh berhak memperoleh penghasilan yang memenuhi penghidupan yang layak bagi kemanusian.

Semenjak adanya otonomi daerah, pemerintah daerah dalam hal ini
Gubernur menetapkan upah minimum sebagai jaring pengaman upah bulanan terendah bagi pekerja/buruh yang terdiri dari upah tanpa tunjangan atau upah pokok termasuk tunjangan tetap. Dalam penetapan tersebut Gubernur tidaklah serta merta langsung menetapkan upah minimum tersebut, harus memperhatikan rekomendasi nilai kebutuhan hidup layak $(\mathrm{KHL})$ dari Dewan Pengupahan. Nilai kebutuhan hidup layak merupakan dasar utama dalam merumuskan besaran upah minimum, namun bukan salah satu faktor yang menjadi acuan tetapi harus juga memperhatikan tingkat produktifitas daerah setempat, pertumbuhan ekonomi, kondisi pasar kerja serta kemampuan usaha yang paling tidak mampu. Sehingga besaran upah minimum tidak harus mutlak sama dengan nilai kebutuhan hidup layak. Nilai Kebutuhan Hidup Layak (KHL) ini didapatkan dengan cara melakukan survei harga kebutuhan di pasar-pasar tradisional berdasarkan 60 item komponen kebutuhan hidup layak.

Survey yang dilakukan oleh Dewan Pengupahan dilakukan di tiga pasar tradisional di Kabupaten Sidoarjo. Ketiga pasar tersebut adalah tiga pasar besar yang ada di Kabupaten Sidoarjo. Pemilihan lokasi pasar tersebut dilihat dari ukuran pasar dan atas dasar kesepakatan tim survey untuk melakukan survey di pasar tersebut, yaitu pasar larangan, pasar wadung asri, dan pasar krian.

Dewan Pengupahan melakukan survei pasar tersebut setiap bulannya dari bulan Januari hingga bulan Agustus. Dari 
delapan bulan ini dihasilkan angka Kebutuhan Hidup Layak (KHL) yang nyata, sedangkan untuk nilai KHL pada bulan kesembilan hingga dua belas diprediksi oleh Badan Pusat Statistik dengan mengacu pada KHL delapan bulan sebelumnya kemudian disatukan menjadi dua belas bulan, dan diambil rata-rata dari dua belas bulan tersebut untuk kemudian dilakukannya pembahasan dalam rapat pleno persamaan pendapat di Dewan Pengupahan yang melibatkan beberapa unsur, yaitu pemerintah, pengusaha, dan pekerja. Adapun materi yang dirundingkan terkait dengan syarat dan kondisi kerja termasuk upah dan komponen upah. Dari hasil yang didapatkan tersebut kemudian menjadi usulan upah minimum tahun berikutnya.

Usulan nilai KHL dari Dewan Pengupahan ini yang kemudian disampaikan kepada Bupati diusulkan ke Gubernur untuk mendapatkan penetapan nilai upah minimum tahun berikutnya. Proses perumusan hingga penetapannya lebih jelasnya dapat dilihat pada Gambar dibawah ini :

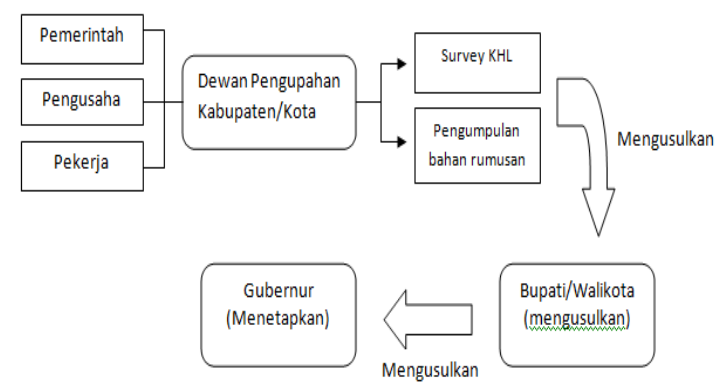

Gambar 2.

Mekanisme Penetapan Upah Minimum

\section{Prinsip dasar Pengupahan dalam Prespektif Islam}

\section{A. Indikator Musyawarah}

Kata musyawarah pada dasarnya hanya digunakan untuk hal-hal yang baik, sejalan dengan makna dasarnya. Sedangkan menurut istilah figh adalah meminta pendapat orang lain atau umat mengenai suatu urusan. Kata musyawarah juga umum diartikan dengan perundingan atau tukar pikiran. Perundingan itu juga disebut musyawarah, karena masingmasing orang yang berunding dimintai atau diharapkan mengeluarkan atau mengemukakan pendapatnya tentang suatu masalah yang di bicarakan dalam perundingan itu.

Dalam hubungan industrial yang menyangkut masalah pengupahan, Islam selalu menganjurkan adanya kesepakatan melalui musyawarah baik dalam menentukan besaran upah tersebut agar masing-masing pihak yaitu antara pengusaha dengan pekerja dapat melaksanakan tugas dan kewajibannya dengan baik tanpa adanya halangan dari salah satu pihak sehingga dapat tercipta hubungan kerja yang baik. Islam mengajarkan bahwa dalam bermuamalah harus didasarkan pada prinsip saling tolong menolong dan mengutamakan rasa keadilan

Menurut Afzalurrahman (1995:297) mengatakan bahwa upah akan ditentukan melalui negoisasi diantara para pekerja, pengusaha, dan negara. Kepentingan pengusaha dan pekerja 
akan diperhitungkan dengan adil samapai pada keputusan tentang upah. Tugas negara adalah memastikan bahwa upah ditetapkan dengan tidak terlalu rendah sehingga menafikan kebutuhan hidup para pekerja, tetapi tidak juga terlalu tinggi sehingga menafikan bagian si pengusaha dari hasil produk bersamanya.

Berdasarkan hasil wawancara dari ke 6 (enam) informan mengenai perundingan dalam perumusan upah minimum yang telah dilakukan. Perundingan yang dilakukan oleh beberapa pihak yang terlibat dalam proses pengupahan, yaitu buruh, pengusaha, dan pemerintah dalam hal ini DISNAKER. Ketiga pihak ini melakukan sebuah perundingan untuk mencapai hasil kesepakatan bersama yang memenuhi kepentingan masing-masing pihak, sehingga tujuan yang telah ditetapkan oleh pemerintah, yaitu tercapainya kesejahteraan buruh dengan dilaksanakannya upah minimum kabupaten dapat diwujudkan. Dalam melakukan perundingan untuk mencapai kesepakatan masing-masing pihak antara pengusaha dengan pekerja hanya sebatas mengusulkan saja bukan dalam batasan menetapkan dan menentukan, penetapannya adalah wewenang dari Gubernur. Baik menerima atau tidaknya pengusulan dari hasil perundingan itu, semua merupakan hak dari Gubernur.

\section{B. Indikator Keadilan}

Berdasarkan hasil wawancara yang dilakukan peneliti kepada ke 6 (enam) informan dapat diketahui bahwa upah minimum yang telah ditetapkan belum menunjukkan adanya keadilan di antara pengusaha dan pekerja. Keadilan menurut cara pandang keduanya berbeda, bilamana pada pengusaha tidak keadilan ini berdasarkan produktivitas kerja dimana upah yang ditetapkan selalu naik setiap tahunnya tetapi tidak dibarengi dengan produktivitas pekerja yang semakin meningkat. Sedang dalam sisi pekerja ketidak adilan ini berdasarkan keahlian kerja dan tingkat senioritas kerja, dimana hal tersebut tidak dipertimbangkan dalam upah minimum tersebut.

Dalam islam upah ditetapkan dengan cara yang paling tepat tanpa harus menindas pihak manapun, setiap pihak memperoleh bagian yang sah dari hasil kerja sama mereka tanpa adanya ketidakadilan terhadap pihak lain. Keadilan berarti menuntut upah kerja yang seimbang dengan jasa yang diberikan.

Dengan demikian, Islam berupaya menciptakan keseimbangan yang adil diantara keduanya, baik dalam hal pemberian upah maupun perlindungan terhadap kepentingan-kepentingan pekerja dan majikan. Para pekerja mendapat upah yang layak tanpa melanggar hak-hak majikannya yang sah. Majikanpun tidak diperbolehkan berlaku sewenang-wenang terhadap pekerja dengan menghilangkan hak-hak pekerja. Sehingga hubungan antara pekerja dan 
majikan berjalan secara baik demi terwujudnya kesejahteraan bersama.

Dalam menetapkan upah, menurut Yusuf Qordhawii (1997:233) ada dua hal yang perlu diperhatikan yaitu nilai kerja dan kebutuhan hidup. Nilai kerja menjadi pijakan penetapan upah, karena tidak mungkin menyamaratakan upah bagi buruh terdidik atau buruh yang tidak mempunyai keahlian, sedangkan kebutuhan pokok harus diperhatikan karena berkaitan dengan kelangsungan hidup buruh.

Islam tidak percaya kepada persamaan yang tetap dalam distribusi kekayaan, karena kemajuan sosial apapun dalam arti yang sebenarnya menghendaki kesempatan sepenuhnya bagi perbedaan upah, Pendekatan Qur'ani dalam hal penentuan upah berdasarkan pertimbangan kemampuan dan bakat ini merupakan suatu hal yang terpenting yang harus diperhitungkan (Manan, 2009:118). Di dalam Islam profesionalisme kerja sangatlah dhargai, sehingga upah seorang pekerja benarbenar didasari pada keahlian dan manfaat yang diberikan oleh si pekerja itu.

Islam mengakui adanya perbedaan di antara berbagai tingkatan pekerjaan, karena adanya perbedaan kemampuan serta bakat yang mengakibatkan perbedaan penghasilan dan hasil material.

\section{Kelayakan}

Dalam penetapan upah secara islam, pengusaha dianjurkan untuk mempertimbangkan ketiga poin berikut ini; pertama, upah minimum harus cukup tinggi agar dapat memenuhi kebutuhankebutuhan dasar para pekerja. Kedua, tanggung jawab ekonomi pekerja, termasuk jumlah keluarganya, harus dipertimbangkan dengan tepat. Ketiga, perbedaan jumlah upah hendaknya dibatasi dalam batas-batas yang wajar sebagaimana yang benarkan dalam perbedaan-perbedaan alami pada sifatsifat pekerjaan.

Berdasarkan hasil wawancara yang dilakukan peneliti kepada ke 6 (enam) informan diketahui bahwa upah minimum tersebut ditetapkan berdasarkan kebutuhan hidup layak, kebutuhan hidup layak tersebut didalamnya mencakup kebutuhan-kebutuhan hidup manusia yang diantaranya kebutuhan pangan, sandang, dan papan. Kebutuhan hidup layak yang ditetapkan terdiri dari 7 item kebutuhan hidup layak yaitu makanan dan minuman, sandang, perumahan, pendidikan, kesehatan, transportasi, serta rekreasi dan tabungan. Yang dimana ketujuh komponen tersebut secara teori islam telah terpenuhi.

Bilamana dari sisi pekerja indikator kelayakan yang masih belum terpenuhi, menurut pekerja upah minimum saat ini masih belum memenuhi kelayakan, karena upah minimum yang ditetapkan ini hanya berdasarkan pekerja lajang saja, sedang pekerja yang telah berkeluarga akan tetap menerima upah minimum pekerja lajang tersebut. Sehingga kebutuhan hidup mereka sebagai 
FirmanSyah, et al/Jurnal Ekonomi Syariah Teori dan Terapan Vol. 4 No. 6 Juni 2017: 434-448; SISTEM UPAH MINIMUM KABUPATEN DALAM PERSPEKTI ISLAM (Studi Kasus Pada Upah Minimum Kabupaten Sidoarjo)

anggota keluarga dirasa masih belum memenuhi unsur kelayakan tersebut.

\section{Kebajikan}

Prinsip kebajikan yang dalam hubungan kerja dapat diterjemahkan sebagai asas kerohanian dan diharapkan mampu menggugah hati nurani para pemilik pekerja untuk dapat menghargai jasa para buruh atau pekerja yang telah memberikan sumbangan untuk mendapatkan kekayaan yang lebih. Islam mengaharuskan bersifat jujur dan adil dalam berhubungan kerja, sehingga tidak akan terjadi eksploitasi yang dapat merugikan salah satu pihak. Dimana buruh yang tidak dibayar secara adil sebagaimana mestinya dari hasil kerja buruh. Sedangkan pengusaha yang dituntut untuk membayar upah buruh melebihi dari kemampuan mereka.

Berdasarkan data yang diperoleh dari hasil wawancara yang dilakukan oleh peneliti bahwa upah yang selama ini ditetapkan selalu adanya perdebatan diantara kedua belah pihak yang samasama saling tidak menerima. Hampir dapat dipastikan bahwa dalam persepsi sipihak kerja inginnya upah itu setinggitingginya sedang persepsi bagi pihak pengusaha inginnya upah itu serendahrendahnya. Perbedaan persepsi ini disebabkan karena adanya perbedaan kepentingan yang di miliki keduanya. Para buruh memperjuangkan haknya untuk memperoleh upah yang layak untuk memperbaiki kualitas hidup. Sementara tidak demikian yang menjadi pertimbangan bagi pengusaha. Karena yang mempertimbangkan pengusaha dan perusahaannya adalah profit, biaya produksi, dan lain-lain untuk keberlangsungan usahanya.

\section{KESIMPULAN}

Dari hasil pembahasan yang telah dijelaskan diatas, maka dapat disimpulkan bahwa proses perumusannya hingga penetapannya upah minimum kabupaten di Kabupaten Sidoarjo adalah masih belum memenuhi kesemua indikator upah yang islami. Seperti halnya dalam perumusan upah, tahapan perumusan upah ini pertama kali dilakukan oleh Dewan Pengupahan dengan melakukan survei kebutuhan hidup layak pada tiga pasar tradisional yaitu pasar wadung asri, krian, dan larangan. Hasil yang didapatkan dalam survei pasar dijadikan pedoman yang kemudian dibahas dalam Dewan Pengupahan dengan berdasarkan musyawarah atau perundingan kedua belah pihak sehingga menghasilkan sebuah kesepakatan bersama. Hasil dari kesepakatan tersebut hanya digunakan sebagai pengusulan saja bukan sebagai penentunya, wewenang penentuan besaran upah minimum berada pada tingkat Gubernur.

Dalam indikator keadilan, indikator kelayakan, dan indikator kebajikan kedua belah pihak masih sama-sama belum menerima kepuasan apa yang menjadi kepentingan mereka, pada pengusaha menekankan bahwa kenaikan upah tidak dibarengi dengan tingkat produktivitas pekerjanya sehingga membuat 
pengusaha merasa keberatan dalam membayar upah minimum tersebut. Sedangkan bagi pekerja menekankan bahwa upah minimum yang layak selama ini hanya dihitung berdasarkan pekerja lajang saja sehingga bagi pekerja yang telah berkeluarga merasa bahwa upah minimum tersebut tidak dapat mencukupi kebutuhan hidup keluarganya. Padahal Islam memberikan pedoman untuk memberikan upah yang sepadan (ajr almitli) dimana upah yang sepadan dengan kerja dan kondisi pekerjaannya, dan tidak ada penganiayaan terhadap pekerja maupun majikan.

\section{DAFTAR PUSTAKA}

Afzalurrahman.1995. Muhammad Sebagai Seorang Pedagang, alih bahasa Dewi Nurjuliati et.al., Jakarta: Yayasan Swarna Bhumi.

Huda, Nurul, dkk. 2008. Ekonomi Makro Islam: Pendekatan Teoritis. Jakarta: Kencana.

Manan, M Abdul. 1997. Teori dan Praktek Ekonomi Islam. Yogyakarta: Dana Bhakti Prima Yasa.

Masruri, Habib. 2011. Pengaruh Sistem Pembagian Upah Islami terhadap Peningkatan Produktivitas Karyawan (Studi pada BMT Ummat Sejahtera dikantor Cabang Utama Semarang). IAIN Walisongo Semarang.

Moleong, Lexy J. 2011. Metodelogi Penelitian Kualitatif, edisi Revisi. Bandung: PT. Remaja Rosdakarya.

Muliawan, $M$ Wahyu. 2011. Analisis Pengaruh Upah Minimum Surabaya Terhadap Penyerapan Tenaga Kerja dengan Menggunakan Volume Investasi sebagai Variabel Intervening Periode 1990-2009. Skripsi tidak diterbitkan program sarjana Universitas Airlangga Surabaya.

Mustofa, Muhammad. 2009. Tinjauan Hukum Islam terhadap Penetapan Upah Minimum Pasal 1 ayat [1] dan [2] dalam Permenakertrans Nomor: Per17/MEN/VIII/2005. Skripsi tidak diterbitkan program sarjana Universitas Islam Negeri Sunan Kalijaga.

Nazir, Muhammad. 2003. Metode Penelitian. Jakarta: Ghalia Indonesia.

Qordhawi, Yusuf. 1997. Norma dan Etika Ekonomi Islam. Jakarta: Gema Insani Press

Shihab, Quraish. 2002. Tafsir Al Misbah Pesan Kesan dan Keserasian Al-Qur'an. Jakarta: Lentera.

Simanjuntak, P ayaman J. 1998. Pengantar Ekonomi Sumber Daya Manusia. Jakarta: Lembaga Penerbit Fakultas Ekonomi Universitas Indonesia.

Sugiyono. 2013. Memahami Penelitian Kualitatif. Bandung: Alfabeta.

Suhendi, Hendi.2011. Fiqih Muamalah, Jakarta: PT Raja Grafindo Persada

Sumarsono, Sony. 2003. Ekonomi Sumber Daya Manusia dan Ketenagakerjaan. Yogyakarta: Graha Ilmu. 2009. Teori dan Kebijakan Publik Ekonomi Sumber Daya Manusia. Yogyakarta: Graha llmu.

Tjandra, Surya, dkk. 2007. Advokasi Pengupahan di Daerah. Jakarta: TURC.

Undang-undang pasal 88 Nomor 13 Tahun 2003 tentang Ketenagakerjaan.

Yin. 2009. Studi Kasus Desain Metode. Jakarta: PT. Grafindo Persada. 